\title{
Integrated stratigraphy and astrochronology of the Messinian GSSP at Oued Akrech (Atlantic Morocco)
}

\author{
F.J. Hilgen ${ }^{\mathrm{a}, *}$, L. Bissoli $^{\mathrm{b}}, \mathrm{S}$. Iaccarino ${ }^{\mathrm{b}}$, W. Krijgsman ${ }^{\mathrm{c}}, \mathrm{R}$. Meijer ${ }^{\mathrm{c}}$, \\ A. Negri ${ }^{\mathrm{d}}$, G. Villa ${ }^{\mathrm{b}}$ \\ a Department of Geology, Faculty of Earth Sciences, Budapestlaan 4, 3584 CD Utrecht, The Netherlands \\ b Department of Earth Sciences, University of Parma, Nuovo Campus Universitario, Parma, Italy \\ c Paleomagnetic Laboratory Fort Hoofddijk, Budapestlaan 17, Utrecht, The Netherlands \\ d Istituto di Scienze del Mare, University of Ancona, Via Brecce Bianche, Ancona, Italy
}

Received 28 March 2000; received in revised form 21 August 2000; accepted 22 August 2000

\begin{abstract}
A much improved high-resolution integrated stratigraphy (calcareous plankton biostratigraphy, magnetostratigraphy, cyclostratigraphy) is presented for the classic section of Oued Akrech (Atlantic Morocco) straddling the Tortonian-Messinian boundary. Magnetobiostratigraphic correlations with time-equivalent and astronomically dated sections in the Mediterranean indicate that cyclic alternations of indurated light beige coloured marls and softer, more clayey and reddish coloured marls are dominantly precession-controlled. Characteristic sedimentary cycle patterns, in particular those reflecting precession-obliquity interference, allow for one possible tuning, thus providing accurate astronomical ages for cycles, calcareous plankton events and magnetic reversals. The tuning further indicates that the reddish layers are the equivalent of sapropels in the Mediterranean. The Messinian Global boundary Stratotype Section and Point (GSSP) has recently been formally defined at the base of the reddish layer of cycle No. 15 in section Oued Akrech. This level coincides closely with the first regular occurrence of the Globorotalia miotumida group and is astronomically dated at 7.251 Ma. The global correlation potential is guaranteed by the straightforward calibration of the Oued Akrech magnetostratigraphy to the geomagnetic polarity time scale, locating the GSSP within C3Br.1r. In the marine realm the calcareous nannofossil genus Amaurolithus provides a series of extremely useful events to delimit the boundary on a global scale. The astronomical tuning guarantees a direct first-order calibration of the Messinian GSSP to the standard geological time scale once, as anticipated, the late Miocene part of the astronomical time scale has been incorporated. (C) 2000 Elsevier Science B.V. All rights reserved.
\end{abstract}

Keywords: Neogene; chronostratigraphy; biostratigraphy; magnetostratigraphy; Messinian; geochronology

\section{Introduction}

The Messinian Stage [1] represents the standard

\footnotetext{
* Corresponding author. Tel.: +31-30-2535173; Fax: +31-30-2535030; E-mail: fhilgen@geo.uu.nl
}

chronostratigraphic unit for the uppermost Miocene and is widely known because of the salinity crisis which occurred in the Mediterranean at that time. Selli [2] eliminated existent inconsistencies in the original definition and argued that the Messinian base should be placed at the level that coincides with the first marked environmental 
change which he regarded as the actual onset of the salinity crisis. The lack of an accurate and high-resolution time control prevented a detailed comparison with the open ocean although calcareous plankton biostratigraphy was successfully employed for correlations with the adjacent Atlantic [3-5]. Recently, however, an excellent age control was obtained for the Messinian both in the Mediterranean [6-8] and in the low-latitude Atlantic Ocean [9]. This age control is based on integrated stratigraphic studies complemented by the astronomical tuning of sedimentary cycles or other cyclic variations in continuous marine successions.

To understand the cause(s) and consequences of the - onset of the - Messinian salinity crisis in detail, a similar age control is needed for that part of the Atlantic that is immediately adjacent to the Mediterranean. For this purpose, the cyclically bedded succession of the classic blue marl of Atlantic Morocco seems to be perfectly suitable, because it has already provided a good to excellent calcareous plankton biostratigraphy, magnetostratigraphy, stable isotope stratigraphy and cyclostratigraphy [10-13]. Moreover, Benson et al. [11] employed image analysis techniques to portray sedimentary cycle patterns in section Ain el Beida in order to astronomically tune that part of the succession that straddles the lower boundary of the reversed Gilbert Chron. The same type of cyclicity is also present in the classic Oued Akrech section of Atlantic Morocco that spans the Tortonian-Messinian (T-M) boundary interval, thus showing the potential of this section for astronomical dating.

Recently, the proposal to define the Messinian Global boundary Stratotype Section and Point (GSSP) at the base of the reddish layer of sedimentary cycle No. 15 in section Oued Akrech has been officially accepted by the International Commission on Stratigraphy (ICS) and ratified by the Executive Committee of the International Union of Geological Sciences $[14,15]$. In this paper we present the much improved integrated stratigraphy of Oued Akrech, including the astronomical tuning of sedimentary cycles, that justifies the selection of this section as Messinian GSSP and that will be instrumental in our understanding of the onset of the - salinity crisis.

\section{Geological setting and section}

The Oued Akrech section is located on the Atlantic side of Morocco, $7 \mathrm{~km}$ SSE of Rabat in a road-cut along a steep bluff next to the Oued Akrech ('oued' = 'wadi' $=$ valley), a tributary of the Bou Regreg river (Fig. 1). It contains the basal part of the classic blue marl of Atlantic Morocco, which straddles the T-M boundary. The blue marl has been subject of numerous studies, reflecting the progress made in Neogene biostratigraphy and integrated stratigraphy (e.g., $[12,13,16-20])$. It is best known from the Bou Regreg river valley where it represents a continuous marine record from the Tortonian into the Pliocene. The stratigraphic succession as exposed in quarries and outcrops has recently been complemented by drilling at Ain el Beida and Salé (e.g., [13]). But, despite the drilling, the classic section of Oued Akrech provides the first and foremost opportunity to investigate the integrated stratigraphy of the basal part of the blue marl.

The entire Oued Akrech road section was studied by Rakic-El Bied et al. and others [12,16-20], while Sierro et al. [5] and the Utrecht-Parma team (this paper) focussed their studies on the well-exposed lower part only. The succession starts with an Upper Tortonian shallow marine sandstone. This $5 \mathrm{~m}$ thick yellowish coloured sandstone overlies Devonian limestones with an angular unconformity, and is followed by an indurated phosphatic layer. This layer is succeeded by glauconitic sandy marls and a $2 \mathrm{~m}$ thick deep marine sandy marl with numerous biogenic components, named the coraline zone. The benthic microfauna indicates that the depositional environment changed rapidly from sublittoral to upper bathyal (palaeodepth $500-700 \mathrm{~m}$ ) at the level of the phosphatic layer [16].

The part of the section that is of relevance for the present study starts directly above the coraline zone and contains the basal part of the blue marl named after its distinct fresh colour. The weath- 

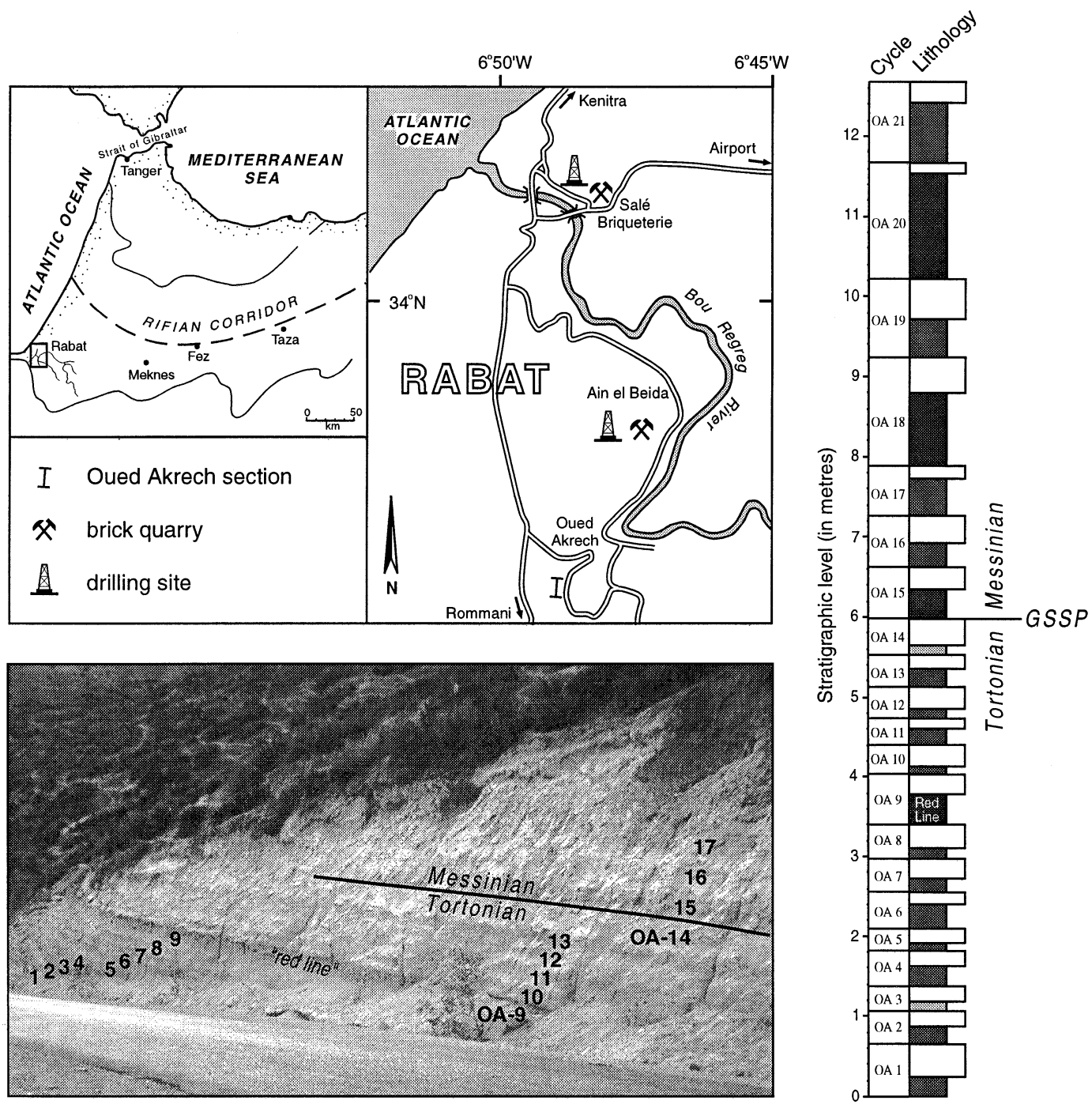

Fig. 1. Location of section Oued Akrech on the Atlantic side of Morocco (NW Africa) and lithological log of the section showing subdivision into sedimentary cycles labelled OA $1-21$.

ered colour of these deep marine marls, however, is a beige one with reddish colour bands (colour cycles; Fig. 1). The upper part of the section is less well-exposed and has not been studied.

\section{Integrated stratigraphy of Oued Akrech}

\subsection{Cyclostratigraphy}

Colour cycles in the blue marl of Atlantic Mo- rocco consist of regular alternations of indurated light beige coloured marls and softer, more clayey and reddish coloured marls [11,19]. At Oued Akrech they become evident from the top of the coraline zone upwards. In total 21 cycles with beds of varying thickness and colour intensity were identified (Fig. 1). Apart from measuring the bed thickness, a visual distinction was made in the colour intensity of the reddish layers between distinct, less distinct and vague. The average cycle thickness of $40-50 \mathrm{~cm}$ in the lower half 


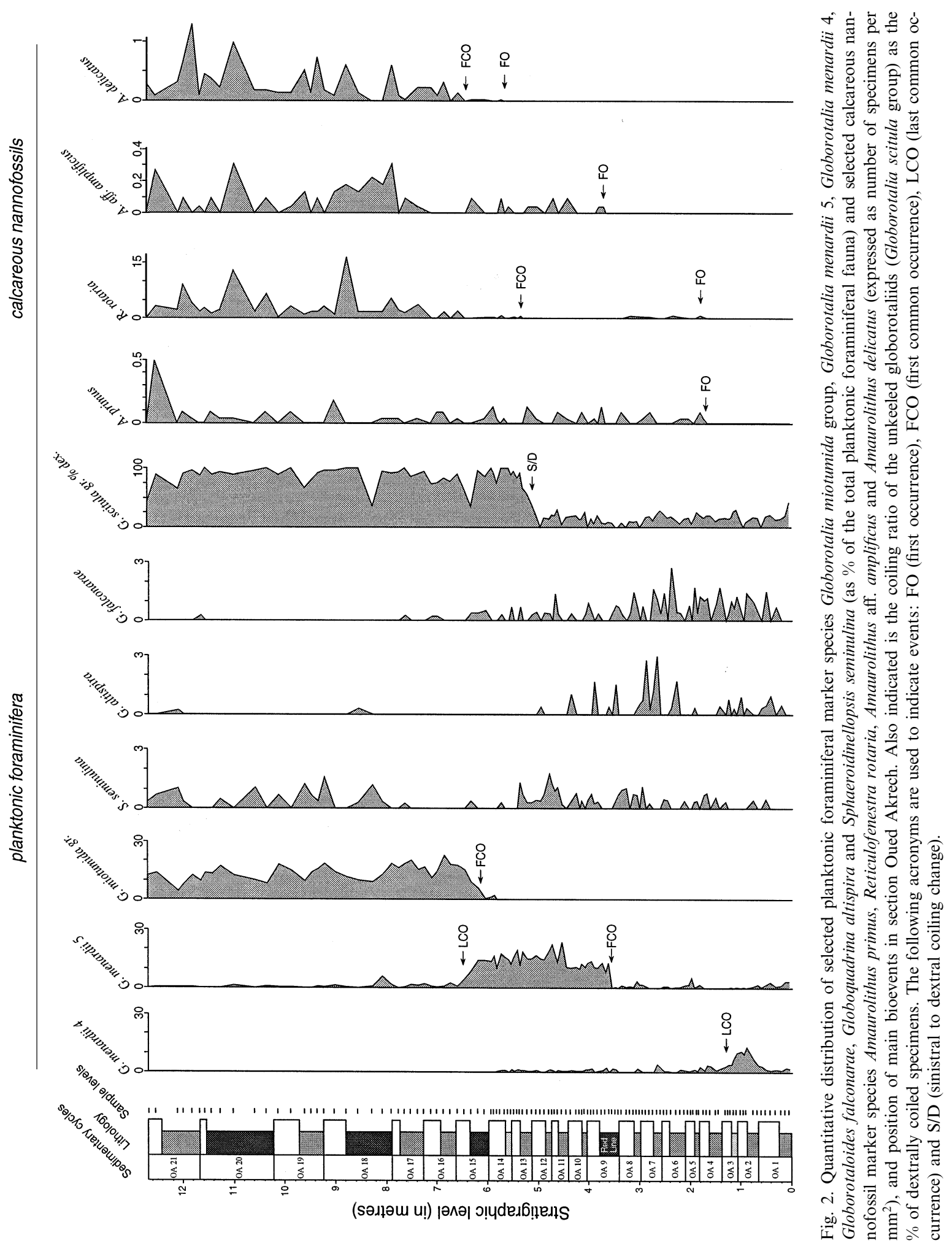


of the section shows a rapid increase to more than $1 \mathrm{~m}$ towards the top of the section. A maximum thickness of around $1.50 \mathrm{~m}$ is reached in cycle 20 .

Also the thickness of the constituent beds of the cycles is variable. Both the reddish and, to a lesser extent, the beige coloured marls reveal marked alternations of thinner and thicker beds in successive cycles. The thickness of the reddish layers in cycles $3,5,(7), 8,10$ and 12 and in cycles 19 and 21 is less than in adjacent cycles, while the thickness of the buff coloured marls is reduced in cycles $6,11,13,(15), 17$ and 20. The thickest reddish layers are also the most prominent if we compare bed thickness data with the colour variations observed in the field.

\subsection{Calcareous plankton biostratigraphy}

\subsubsection{Planktonic foraminifera}

A quantitative analysis of the planktonic foraminifera was carried out on 121 samples in the larger than $125 \mu \mathrm{m}$ fraction. For each sample 200 specimens were counted in splits (using an Otto microsplitter) and classified at the specific level. Planktonic foraminifera are abundant in all samples. The preservation is generally good but is better in the red layers than in the beige layers. The detritic component is generally minor; phosphatic and glauconitic grains are found in the basal part of the section. The low percentages of foraminiferal fragments and indeterminable specimens suggest that preservational effects are generally of minor importance.

The quantitative record of the most important marker species reveals the following events in stratigraphic order (Fig. 2): the Globorotalia menardii 4 last common occurrence (LCO) of Tjalsma [21], the G. menardii 5 first common occurrence (FCO) of Tjalsma [21], a prominent sinistral to dextral (S/D) coiling change in the Globorotalia scitula group, and the Globorotalia miotumida group ${ }^{1}$ first regular occurrence (FRO).

The same events have also been identified in previous biostratigraphic studies of Oued Akrech and the surrounding area [5,10,13,17-20,25-27], although a comparison cannot be made without adding some taxonomic remarks. The FRO of the G. miotumida group marks the turnover in the keeled globorotaliids from assemblages dominated by dextrally coiled $G$. menardii 5 to assemblages dominated by sinistrally coiled $G$. miotumida and thus corresponds to the G. menardii/G. miotumida replacement (PF event 3 of [3-5]; $[13,20,27,28])$. This event slightly predates or coincides with the FO of conical morphotypes $(G$. conomiozea FO of [17,27]; G. conomiozea FCO of $[13,16])$.

The FCO of dextrally coiled G. menardii 5 corresponds, as regards stratigraphic position, to $\mathrm{PF}$ event 2 of [5], and the G. menardii S/D coiling change observed by Benson and Rakic-El Bied and Barbieri [16,20], but significantly postdates the same coiling change reported by Hodell et al. [13] from the Salé drill core. Also our data reveal an overlap in the ranges of the dominantly sinistrally coiled $G$. menardii 4 and the dominantly dextrally coiled G. menardii 5 (Fig. 2; see also [25]), indicating that the G. menardii coiling direction may already become sporadically dextral in the interval below the G. menardii 5 FCO where keeled globorotaliids are less frequent or even absent. Finally, the G. menardii 4 LCO (PF event 1 of [5]) has only been recognised by Sierro et al. and Krijgsman et al. [5,25] because these are the only studies in which a similar taxonomic concept and quantitative approach are applied.

The prominent coiling shift in the G. scitula

\footnotetext{
1 Recent views argue that G. conomiozea and G. conoidea are junior synonyms of $G$. miotumida [22], suggesting that the $G$. conomiozea group should be renamed the G. miotumida group. Furthermore Scott [23] argued that the Mediterranean representatives are comparable but not fully identical with the New Zealand G. miotumida and suggests that the two groups represent separate lineages. Since in New Zealand G. miotumida first occurs in the middle Miocene [22], one may speculate that early representatives of this species have been carried into northern mid-latitudes after which they invaded the Mediterranean during early Messinian climatic cooling [24]. In this view, Mediterranean representatives root into New Zealand populations but may become genetically isolated from their parent stock. Morphologically, however, the differences are small [23] and for that reason we prefer maintaining the label G. miotumida group for those Mediterranean globorotaliids showing a planoconvex axial outline, crescent-shaped chambers, arched aperture, and dominantly left-coiling.
} 
group has previously been reported from Oued Akrech by Sierro et al. ([5]; their PF event A). Above this shift, the G. scitula coiling direction reveals some well-defined higher frequency changes while the number of dextral forms increases again at the very base of our section. Finally, secondary marker species Sphaeroidinellopsis seminulina, Globoquadrina altispira and Globorotaloides falconarae are less frequently observed and become rare and discontinuously present in the upper part of the section.

\subsubsection{Calcareous nannofossils}

Calcareous nannofossils are abundant and generally well preserved. Sample preparation followed standard techniques [29]. Quantitative analyses were performed with a light microscope at $1250 \times$ magnification, and counting at least 300 specimens per sample. Frequencies of the Amaurolithus group, which is usually rare, were estimated by counting the number of specimens encountered in 900 fields of view at $1250 \times$ magnification $\left(=22.5 \mathrm{~mm}^{2}\right)$. A separate count of Reticulofenestra rotaria in a fixed area of $9 \mathrm{~mm}^{2}$ was also performed. In both cases, results were converted to number $/ \mathrm{mm}^{2}$. Results of our quantitative calcareous nannofossil study reveal the following events in stratigraphic order (Fig. 2): the Amaurolithus primus FO, Reticulofenestra rotaria FO, $A$. aff. amplificus $\mathrm{FO}^{2}, R$. rotaria $\mathrm{FCO}, A$. delicatus FO and $A$. delicatus FCO.

Of these events, only the FOs of $A$. primus and A. delicatus have been recognised in previous studies of the blue marl of Atlantic Morocco $[5,16]$. We pinpointed the $A$. primus FO at a slightly lower stratigraphic position in Oued Akrech than Benson and Rakic-El Bied [16] while Sierro et al. [5] located the same event significantly higher in the section. The position of the A. delicatus FO is consistent with the position reported by Sierro et al. [5] and, like in the Mediterranean, coincides closely with the T-M boundary as approximated by the G. miotumida group FRO. The position of the two Amaurolithus

\footnotetext{
${ }^{2}$ See Negri and Villa [29] for a taxonomic note on this species.
}

events at Oued Akrech is also in agreement with their position in the Ain el Beida core [16], although the $A$. primus $\mathrm{FO}$ is observed at a slightly higher stratigraphic level at the latter site. The discrepancies observed thus far in the position of the two events are small and can easily be explained by a different analytical approach and sample resolution. Major discrepancies, however, are found if the position of these events is compared with their position in the Sale drill core, where they occur at a much lower stratigraphic level relative to the magnetostratigraphy and planktonic foraminiferal biostratigraphy [13]. Clearly, these discrepancies cannot be attributed to differences in sample resolution but must be explained by downward contamination (whatever the cause) or by fundamental differences in biostratigraphic methods (including taxonomy).

\subsection{Magnetostratigraphy}

The first magnetostratigraphic results from Oued Akrech were presented by Hodell et al. [12], who identified only one normal-polarity chron in the interval straddling the $\mathrm{T}-\mathrm{M}$ boundary. The magnetostratigraphy from the drill holes at Ain el Beida and Sale showed two normal chrons (C3Bn and $\mathrm{C} 3 \mathrm{Br} .1 \mathrm{n})$ in the correlative interval $[11,13]$, in agreement with the magnetostratigraphy of $\mathrm{T}-\mathrm{M}$ boundary sections in the Mediterranean [30,31].

Section Oued Akrech was sampled with a resolution of five levels per sedimentary cycle for magnetostratigraphic studies. The natural remanent magnetisation (NRM) of standard $10.4 \mathrm{~cm}^{3}$ specimens was measured on a $2 \mathrm{G}$ Enterprises DCSQUID cryogenic magnetometer by means of stepwise thermal (TH) demagnetisation procedures. Up to 14 demagnetisation steps were applied until complete demagnetisation of the samples was reached. Least-square analysis was applied to determine the component directions of the NRM, chosen by inspection of Zijderveld demagnetisation diagrams (Fig. 3C-H).

Samples from the lower part of the section (up to OA 9) are characterised by relatively low NRM intensity (0.1-1 mA/m; Fig. 4), low IRM intensity (100-1000 mA/m; Fig. 3A), and low susceptibility 


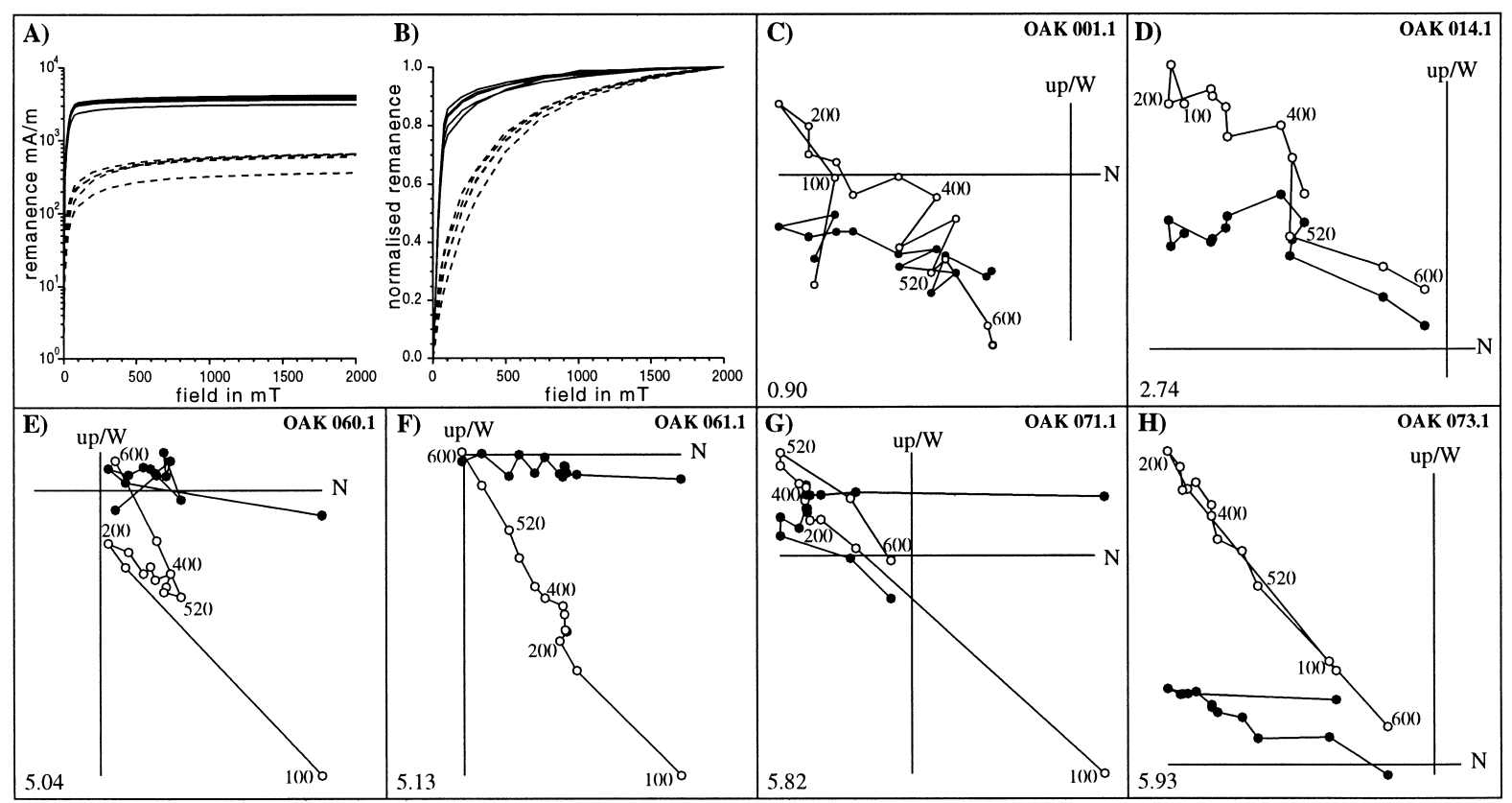

Fig. 3. A,B: IRM acquisition curves (absolute and normalised values) of selected samples from the lower part (dashed lines) and upper part (solid lines) of section Oued Akrech. The initial steep rise ( $>200 \mathrm{mT}$ ) points to magnetite, the gradual increase at higher fields suggests the additional presence of maghaemite and/or haematite. $\mathrm{C}-\mathrm{H}$ : Zijderveld diagrams showing the thermal demagnetisation results of selected samples from section Oued Akrech. Filled symbols denote the projection of the vector endpoints on the horizontal plane; open symbols denote projections on the vertical plane; values represent temperatures in ${ }^{\circ} \mathrm{C}$; stratigraphic levels are in the lower left-hand corner.

$\left(40-70 \times 10^{-6} \mathrm{SI}\right)$. Normalised IRM acquisition curves indicate the combined presence of lowand high-coercivity minerals, probably iron oxides like magnetite, maghaemite and haematite (Fig. 3B). Zijderveld diagrams are rather scattered but reveal reversed components in the temperature range of $200-600^{\circ} \mathrm{C}$ (Fig. 3C). Several (randomly spaced) diagrams bypass the origin, suggesting the additional presence of a high-temperature $\left(>600^{\circ} \mathrm{C}\right)$ component. Zijderveld diagrams from the interval OA 9-11 are in many cases difficult to interpret and often show strong clustering in the 200- $600^{\circ} \mathrm{C}$ temperature range. Samples from the upper part of the section (OA 13-21) have a much higher NRM intensity (1-10 mA/m; Fig. 4), higher IRM intensity (1000-10,000 mA/m; Fig. 3A) and higher susceptibility $\left(100-120 \times 10^{-6}\right.$ SI). Normalised IRM curves reveal a low-coercivity mineral like magnetite as the dominant carrier of the magnetisation. Zijderveld diagrams are gen- erally straightforward and show both normal and reversed components in the temperature range of $200-600^{\circ} \mathrm{C}$ (Fig. 3F,H). Our detailed magnetostratigraphic record of Oued Akrech reveals the presence of two normal chrons in the interval straddling the T-M boundary (cycles OA 13-14 and OA 16-19; Fig. 4). Some samples with a position very close to a palaeomagnetic reversal show a three-component NRM with a 'delayed' $520-600^{\circ} \mathrm{C}$ component derived from the younger opposite-polarity chron (Fig. 3E,G).

\section{Integrated stratigraphy and astronomical dating}

Biostratigraphic correlations to astronomically dated T-M boundary sections in the Mediterranean are straightforward and reveal that the order of calcareous plankton events in Morocco is almost identical between the examined sections 

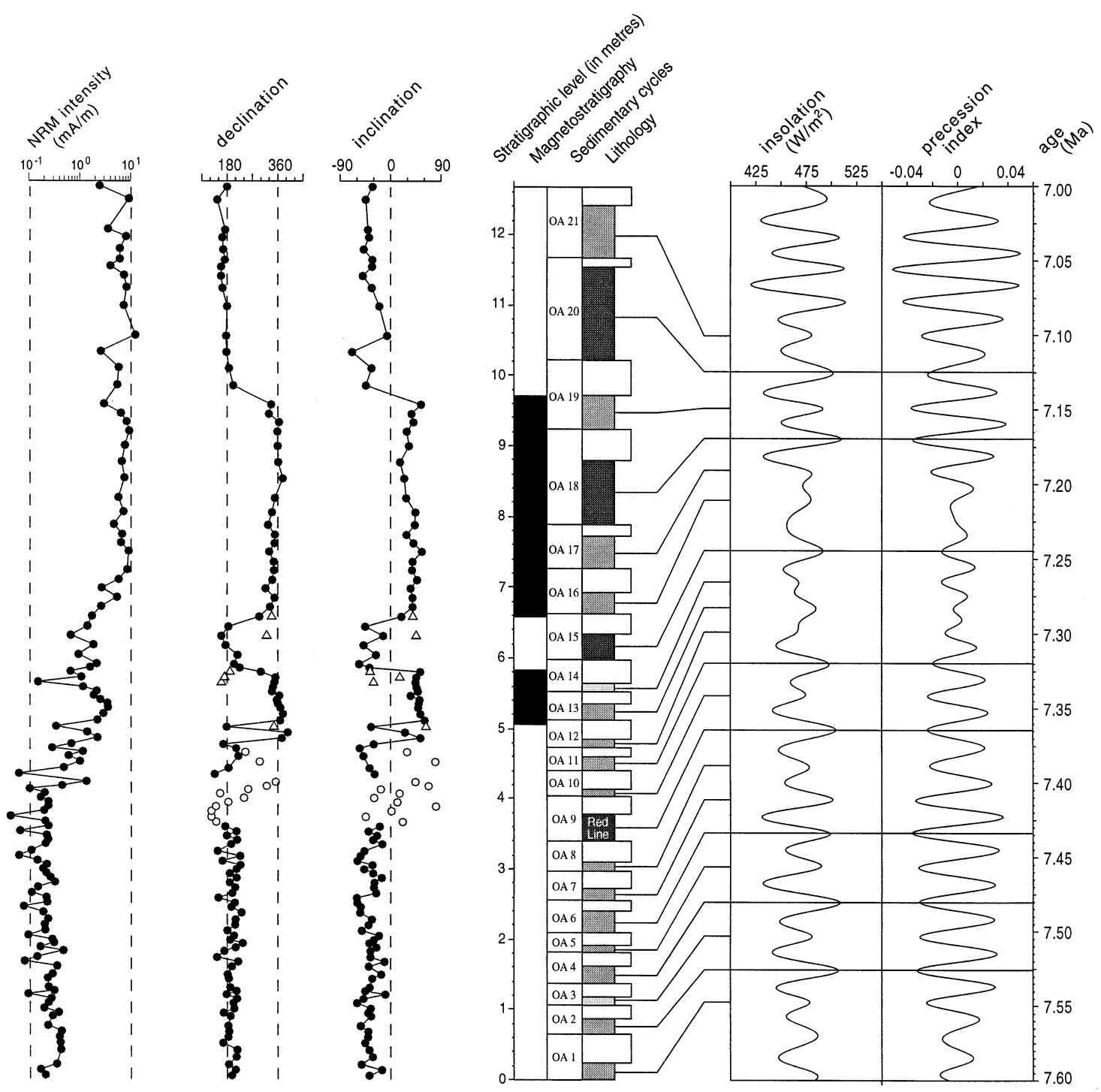

Fig. 4. NRM intensity and magnetostratigraphy of the Oued Akrech section and astronomical tuning of cycles OA 1-21 to the $65^{\circ}$ Nlat summer insolation curve calculated from solution $\mathrm{La}_{(1,1)}$ with present-day values for the dynamical ellipticity of the Earth and tidal dissipation by the Moon.

[29,31-33]. The correlations hint at a strong precessional forcing of the basic colour cycles. This observation confirms earlier interpretations of Benson et al. [11] for similar colour cycles at nearby Ain el Beida, and reveals that section Oued Akrech is potentially suitable for astronomical dating. Initially, the astronomical tuning of the colour cycles was hampered by the fact that the phase relation of - the constituent beds of - the colour cycles with precession was unknown. Only one calibration is possible however if we interpret the thin-thick alternations of the reddish layers to reflect precession-obliquity interference and apply the same astronomical solution $\left(\operatorname{La90}_{(1,1)}\right)$ and target curve $\left(65^{\circ} \mathrm{Nlat}\right.$ summer insolation) used for dating time-equivalent cycles in the Mediter- 
Table 1

Astronomical ages for the mid-points of individual beds of sedimentary cycles OA 1-21 based on the tuning shown in Fig. 5

\begin{tabular}{|c|c|c|c|c|c|c|c|c|c|c|c|}
\hline Cycle & Lithology & $\begin{array}{l}\text { Pre- } \\
\text { cession }\end{array}$ & Insolation & Cycle & Lithology & $\begin{array}{l}\text { Pre- } \\
\text { cession }\end{array}$ & Insolation & Cycle & Lithology & $\begin{array}{l}\text { Pre- } \\
\text { cession }\end{array}$ & Insolation \\
\hline & white & 7.400 & 7.400 & & white & 7.255 & 7.257 & & white & 7.089 & 7.090 \\
\hline \multirow[t]{2}{*}{ OA 7} & red & 7.412 & 7.411 & OA 14 & red & 7.265 & 7.266 & OA 21 & red & 7.100 & 7.100 \\
\hline & white & 7.423 & 7.423 & & white & 7.275 & 7.272 & & white & 7.113 & 7.110 \\
\hline \multirow[t]{2}{*}{ OA 6} & red & 7.434 & 7.434 & OA 13 & red & 7.283 & 7.283 & OA 20 & red & 7.126 & 7.126 \\
\hline & white & 7.445 & 7.445 & & white & 7.290 & $*$ & & white & 7.138 & 7.139 \\
\hline \multirow[t]{2}{*}{ OA 5} & red & 7.457 & 7.456 & OA 12 & red & 7.299 & $*$ & OA 19 & red & 7.149 & 7.149 \\
\hline & white & 7.468 & 7.468 & & white & 7.309 & 7.308 & & white & 7.159 & 7.159 \\
\hline \multirow[t]{2}{*}{ OA 4} & red & 7.480 & 7.481 & OA 11 & red & 7.319 & 7.320 & OA 18 & red & 7.170 & 7.170 \\
\hline & white & 7.492 & 7.493 & & white & 7.331 & 7.332 & & white & 7.181 & 7.182 \\
\hline \multirow[t]{2}{*}{ OA 3} & red & 7.503 & 7.503 & OA 10 & red & 7.342 & 7.341 & OA 17 & red & 7.191 & 7.193 \\
\hline & white & 7.515 & 7.514 & & white & 7.353 & 7.351 & & white & 7.203 & 7.201 \\
\hline \multirow[t]{2}{*}{ OA 2} & red & 7.526 & 7.526 & OA 9 & red & 7.364 & 7.364 & OA 16 & red & 7.215 & 7.210 \\
\hline & white & 7.537 & 7.538 & & white & 7.376 & 7.378 & & white & 7.234 & 7.228 \\
\hline OA 1 & red & 7.548 & 7.548 & OA 8 & red & 7.388 & 7.389 & OA 15 & red & 7.245 & 7.245 \\
\hline
\end{tabular}

Astronomical ages refer to non-lagged ages of the correlative precession minimum/maximum and insolation maximum/minimum. *No corresponding peak in the insolation time series.

ranean (Fig. 4; Table 1) 3 $^{3}$ This calibration suggests that the reddish layers correspond to precession minima/summer insolation maxima and, thus, to sapropels in the Mediterranean. The inferred relationship has subsequently been confirmed by quantitative planktonic foraminiferal and stable isotope records from nearby Ain el Beida which reveal the same characteristic signal in the reddish layers as found in Mediterranean sapropels (Globigerinoides spp. maxima and $\delta^{18} \mathrm{O}$ minima: Gaboardi, personal communication).

The tuning can be used to accurately determine the sediment accumulation rate which varies between 1.5 and $3.5 \mathrm{~cm} / \mathrm{kyr}$ with an increase to $6 \mathrm{~cm} / \mathrm{kyr}$ higher in the section. The latter is signified by the rather abrupt increase in cycle thickness from cycle 17 upwards which, in turn, coincides with the conspicuous increase in the

\footnotetext{
${ }^{3}$ We selected solution $\operatorname{La}_{(1,1)}$ because there is a good to excellent agreement between the details in its insolation time series and the sedimentary cycle patterns in the Mediterranean over the last 9 Myr [6,34], thus including the time interval of the present study. This agreement indicates that the uncertainty in the exact phasing of the orbital cycles must be very small since the details include precession-obliquity interference patterns which are very sensitive to small changes in the astronomical solution (see [34]).
}

precessional and insolation amplitude starting around $7.18 \mathrm{Ma}$. This amplitude increase is related to the eccentricity modulation of precession following the $400 \mathrm{kyr}$ eccentricity minimum dated around 7.25 Ma. This effect is amplified because the preceding interval in addition marks an eccentricity minimum related to the long-term 2.35 Myr cycle. The effect of the same long-term modulation cycle of eccentricity is clearly discernible in time-equivalent but longer sections in the Mediterranean [6]. Typically, the expression of the $100 \mathrm{kyr}$ cycle is almost completely lacking during a 2.35 Myr eccentricity minimum, resulting in a prolonged interval with relatively low and constant amplitude variations in precession and strong precession-obliquity interference in the insolation time series. This provides a clear explanation for the lack of expression of the $100 \mathrm{kyr}$ cycle and the persuasiveness of precession-obliquity interference patterns in the sedimentary cycle record of Oued Akrech. In this particular time interval, precession-obliquity interference is further enhanced by maximum amplitude variations in obliquity related to the $1.2 \mathrm{Myr}$ cycle [35].

The astronomical tuning of Oued Akrech implies that the section can be correlated cyclostratigraphically in detail ('bed-to-bed') to the sections in the Mediterranean (Fig. 5). These correlations 
Table 2

Stratigraphic position, cycle position and astronomical ages of calcareous plankton events and magnetic polarity reversals in section Oued Akrech, and comparison with published astronomical ages for the same events/reversals in Mediterranean sections

\begin{tabular}{|c|c|c|c|c|c|c|c|c|c|}
\hline \multirow[t]{2}{*}{ Taxon/reversal } & \multirow[t]{2}{*}{ Event } & \multirow[t]{2}{*}{ Position } & \multicolumn{2}{|l|}{ Oued Akrech } & \multirow{2}{*}{$\begin{array}{l}\text { Fanero- } \\
\text { meni } \\
\text { age }\end{array}$} & \multirow{2}{*}{$\begin{array}{l}\text { Kastelli } \\
\text { age }\end{array}$} & \multirow{2}{*}{$\begin{array}{l}\text { Metochia } \\
\text { age }\end{array}$} & \multirow{2}{*}{$\begin{array}{l}\text { M. Casino } \\
\text { age }\end{array}$} & \multirow{2}{*}{$\begin{array}{l}\text { HKL- } \\
\text { LSZ95 } \\
\text { age }\end{array}$} \\
\hline & & & cycle & age & & & & & \\
\hline \multicolumn{10}{|c|}{ Planktonic foraminifera } \\
\hline G. menardii 5 & $\mathrm{~L}(\mathrm{C}) \mathrm{O}$ & 6.46 & beige OA 15 & 7.229 & - & - & $7.243-7.255$ & - & - \\
\hline G. miotumida gr. & $\mathrm{FCO}$ & $6.06-6.20$ & reddish OA 14 & $7.243-7.248$ & $7.243-7.246$ & $7.242-7.252$ & $7.240-7.244$ & $7.239-7.244$ & 7.243 \\
\hline G. scitula & $\mathrm{s} / \mathrm{d}$ & $5.13-5.22$ & reddish OA 14 & $7.283-7.286$ & - & - & $7.283-7.290$ & $7.305-7.311$ & - \\
\hline G. menardii 5 & $\mathrm{FCO}$ & $3.54-3.61$ & reddish OA 9 & $7.363-7.366$ & $7.356-7.362$ & $7.354-7.359$ & $7.356-7.359$ & $7.370-7.374$ & 7.358 \\
\hline G. menardii 4 & $\mathrm{LCO}$ & $1.15-1.21$ & reddish OA 3 & $7.497-7.501$ & $7.514-7.522$ & $7.515-7.522$ & $7.510-7.515$ & $7.507-7.512$ & 7.515 \\
\hline \multicolumn{10}{|c|}{ Calcareous nannofossils } \\
\hline A. delicatus & FCO & $6.46-6.60$ & beige OA 15 & $7.221-7.229$ & - & - & - & - & - \\
\hline A. delicatus & $\mathrm{FO}$ & $5.67-5.74$ & beige OA 14 & $7.260-7.262$ & $7.252-7.253$ & - & - & $7.221-7.229$ & - \\
\hline R. rotaria & $\mathrm{FCO}$ & $5.31-5.37$ & beige OA 13 & $7.276-7.279$ & $7.265-7.270$ & - & - & $7.221-7.229$ & - \\
\hline A. aff. amplificus & $\mathrm{FO}$ & $3.68-3.75$ & reddish OA 9 & $7.357-7.360$ & $7.390-7.393$ & - & - & $7.431-7.437$ & - \\
\hline R. rotaria & FO & $1.74-1.83$ & reddish OA 5 & $7.458-7.466$ & $7.422-7.426$ & - & - & $7.401-7.408$ & - \\
\hline A. primus & FO & $1.68-1.74$ & beige OA 4 & $7.466-7.470$ & $7.432-7.435$ & - & - & $7.443-7.449$ & - \\
\hline \multicolumn{10}{|l|}{ Magnetic reversal } \\
\hline C3Bn (y) & $\mathrm{N}>\mathrm{R}$ & $9.61-9.88$ & beige OA 19 & $7.141-7.146$ & - & $7.097-7.111$ & $7.109-7.136$ & - & 7.104 \\
\hline C3Bn (o) & $\mathrm{R}>\mathrm{N}$ & $6.60-6.74$ & reddish OA 16 & $7.212-7.221$ & $7.206-7.221$ & $7.211-7.217$ & $7.219-7.226$ & - & 7.213 \\
\hline C3Br.1n (y) & $\mathrm{N}>\mathrm{R}$ & $5.82-5.88$ & beige OA 14 & $7.254-7.256$ & $7.252-7.267$ & $7.258-7.265$ & $7.260-7.271$ & - & 7.259 \\
\hline C3Br.1n (o) & $\mathrm{R}>\mathrm{N}$ & $5.04-5.13$ & beige OA 12 & $7.286-7.288$ & $7.302-7.307$ & 7.299-7.305 & $7.304-7.319$ & - & 7.304 \\
\hline C3Br.2n (y) & $\mathrm{N}>\mathrm{R}$ & - & - & - & $7.455-7.458$ & $7.458-7.465$ & $7.477-7.481$ & - & 7.458 \\
\hline C3Br.2n (o) & $\mathrm{R}>\mathrm{N}$ & - & - & - & $7.483-7.502$ & $7.491-7.499$ & $7.520-7.525$ & - & 7.495 \\
\hline C4n.1n (y) & $\mathrm{N}>\mathrm{R}$ & - & - & - & $7.532-7.538$ & $7.522-7.539$ & $7.548-7.555$ & - & 7.535 \\
\hline
\end{tabular}

Note that all these ages are $3 \mathrm{kyr}$ older than previously published because of our preference for using non-lagged ages of sedimentary cycles.

$\mathrm{s} / \mathrm{d}=$ coiling shift from sinistral to dextral; bold data mark ages of bio-events in the Oued Akrech section and the Mediterranean (Mediterranean ages after [6]).

reveal remarkable similarities despite the fact that cycles may lack a (distinct) lithological expression in the Mediterranean at times of low-amplitude (minimal) astronomical forcing. The thickest and distinct reddish layers of cycles 18 and 20 correlate well with two prominent sapropels in Mediterranean sections. These sapropels succeed the thick homogeneous marly interval which usually does not contain sapropels and which corresponds to the $400 \mathrm{kyr}$ eccentricity minimum at $7.25 \mathrm{Ma}$. Also the interference pattern is similar with the reddish layer/sapropel of the intermediate cycle being less prominent and thick. The two other prominent reddish layers (of cycles 9 and 15) at Oued Akrech correlate well with the two thin sapropels that occur in the Metochia section in the thick homogeneous marl interval around 7.25 Ma. Finally, the upper two of the three distinct sapropels in the Mediterranean which are found in the interval that corresponds to the $400 \mathrm{kyr}$ eccentricity maximum around $7.45 \mathrm{Ma}$ correlate well with the thicker (and more prominent) reddish layers of cycles 2 and 4 at Oued Akrech, which similarly reflect precession-obliquity interference. It should be emphasised here that Oued Akrech is the only section in which all the precession/insolation cycles in the $\mathrm{T}-\mathrm{M}$ boundary interval are recorded as individual sedimentary cycles.

The astronomical tuning of Oued Akrech reveals that first-order planktonic foraminiferal events are recorded in the correlative cycle in the Mediterranean (Fig. 5; Table 2). Also the prominent coiling change in the $G$. scitula group occupies the same (cyclo)stratigraphic position and, thus, has the same age as in the Mediterranean. Even short-term incursions of left-coiling $G$. scitula appear to correlate with similar incursions in the Mediterranean and adjacent Atlantic 


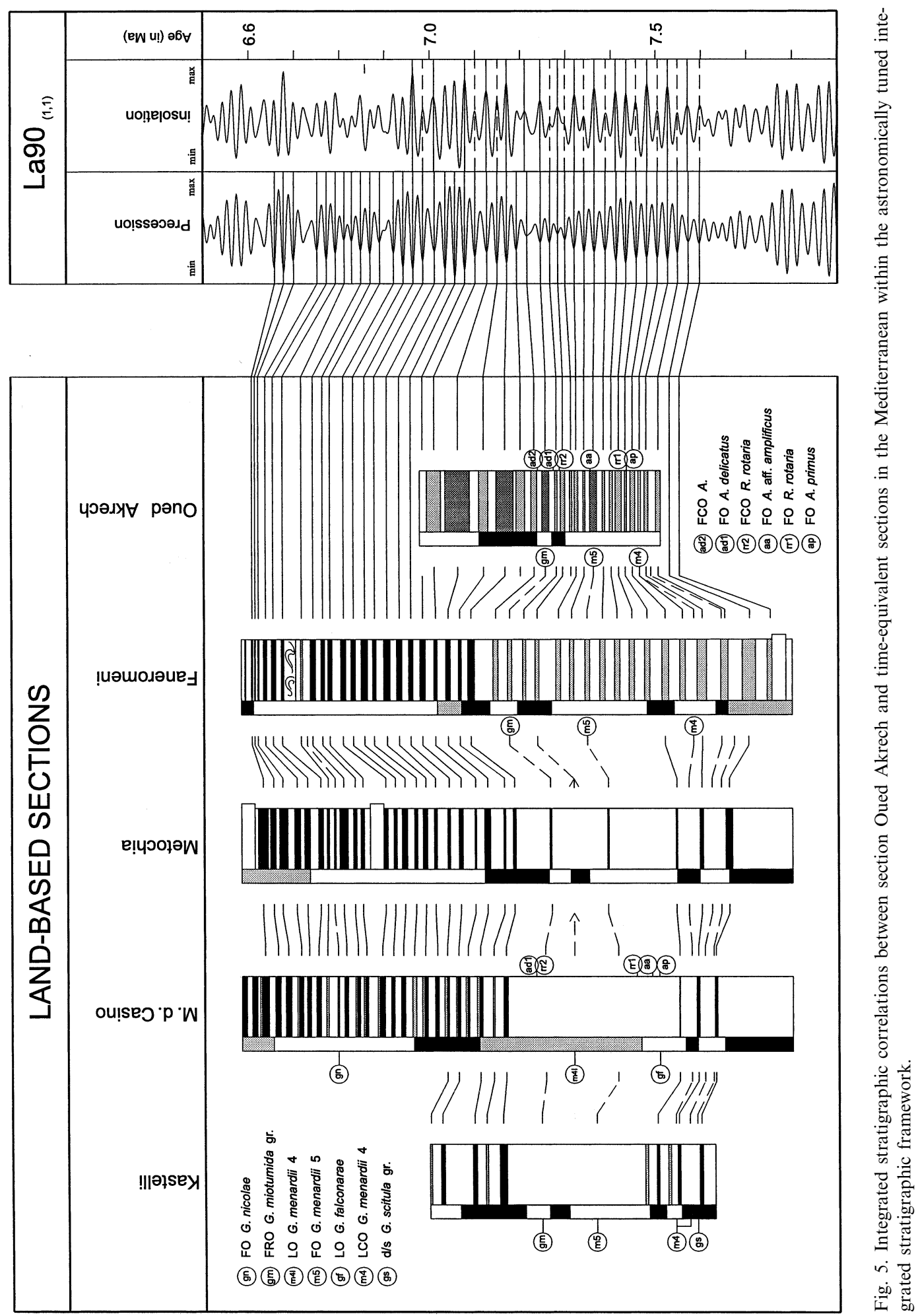


([5,32]; unpublished data). The increase in dextral forms at the base of section Oued Akrech corresponds with the base of the long interval with dominantly left-coiling $G$. scitula in the Mediterranean [32]. Secondary events like the G. falconarae LO and the Sphaeroidinellopsis seminulina $\mathrm{L}(\mathrm{C}) \mathrm{O}$, however, are delayed with respect to the Mediterranean. The position of calcareous nannofossil events relative to the astronomically tuned cyclostratigraphy reveals generally minor discrepancies of $1-2$ cycles $(\sim 20-40 \mathrm{kyr}$ ) (Table 2 ).

The calibration of the magnetostratigraphy across the T-M boundary to the APTS is straightforward through the integrated stratigraphic correlations to the well-calibrated Mediterranean sections (Fig. 5). The two normal-polarity intervals and intervening reversed interval thus correspond - from bottom to top - to C3Br.1n, C3Br.1r and $\mathrm{C} 3 \mathrm{Bn}$. But the integrated stratigraphic correlations also reveal discrepancies, implying that the C3Br.2n (y), C3Br.2n (o) and C4n.1n (y) reversal boundaries are not registered and, as a consequence, that the reversed signal in the lower part of the section is of secondary origin. The high-resolution cyclostratigraphic correlations to Mediterranean sections having a reliable magnetostratigraphy can be used to estimate the stratigraphic position of the 'missing' reversals in this part of the section having adverse magnetic properties. The correlations indicate that the position of the $\mathrm{C} 4 \mathrm{n}-\mathrm{C} 3 \mathrm{Br}$ boundary is expected to be within the beige bed of cycle 1 , and that the C3Br.2n reversal boundaries are located in the beige bed of cycle 5 and the base of the reddish layer of cycle 7. The thus extrapolated magnetostratigraphy of Oued Akrech reveals an excellent fit, including stratigraphic thicknesses of individual polarity zones, with the magnetostratigraphy of the corresponding interval in the Salé drill core [13].

\section{The Messinian GSSP at Oued Akrech}

Numerous sections are qualified for locating the Messinian GSSP since they contain the T-M boundary interval in a continuous marine succession (Monte del Casino in northern Italy; Faneromeni, Potamidha and Kastelli on Crete, Greece;
Metochia on Gavdos, Greece; Oued Akrech, Morocco). All these sections have been astronomically dated and cyclostratigraphically correlated $[6,31,32]$, and fulfil most if not all the requirements recommended by the ICS [36]. But the Oued Akrech section located on the Atlantic side of Morocco is the most suitable section if the most important criteria for the late Neogene time interval are taken into consideration (calcareous plankton biostratigraphy, magnetostratigraphy and astronomically dated cyclostratigraphy). The fact that the GSSP is located outside its type area (Sicily) and even outside the Mediterranean is not considered a problem in view of the excellent and straightforward integrated stratigraphic correlations of Oued Akrech to sections within the Mediterranean (Fig. 5). In fact it is an important additional argument because it emphasises that the Messinian is a global chronostratigraphic unit and not a Mediterranean stage of regional significance only, as argued for instance by Benson and Rakic-El Bied and Benson and Hodell [16,37].

Recently, the Messinian GSSP has formally been designated at the base of the reddish layer of cycle No. 15, i.e., at a level that coincides closely with the FRO of the G. miotumida group in the middle of reversed subchron C3Br.1r [15]. This level is dated astronomically at $7.251 \mathrm{Ma}$. The global correlation potential of the GSSP is assured by the straightforward calibration of the Oued Akrech magnetostratigraphy to the geomagnetic polarity time scale, thus allowing identification of the boundary in continental settings lacking a direct biostratigraphic control. In the marine realm, the calcareous nannofossil genus Amaurolithus provides a series of extremely useful events to delimit the boundary on a global scale. The $A$. primus and $A$. delicatus FOs predate the boundary while the $A$. amplificus s.s. FO postdates the boundary (see $[38,39]$ ). The turnover of dominantly dextrally coiled assemblages of $G$. menardii 5 by dominantly sinistrally coiled assemblages of the $G$. miotumida group can be used to delimit the boundary in the Mediterranean and the adjacent North Atlantic [3-5]. The Messinian GSSP at Oued Akrech falls within zone NN11b of [40] and zone CN9b of [41] of standard calcareous 
nannofossil zonal schemes. In terms of planktonic foraminiferal zonations, the GSSP falls within (sub)tropical zone M13b (Globigerinoides extremus/Globorotalia plesiotumida-Globorotalia lenguaensis interval subzone) of [42] and the Globorotalia suturae subzone of [43], and coincides with the transitional Mt9-Mt10 zonal boundary (Globorotalia conomiozea/Globorotalia mediterraneaGloborotalia sphericomiozea interval subzone) of [42].

Stable isotopes provide yet another correlation tool. The Late Miocene Global Carbon isotope shift (in $\delta^{13} \mathrm{C}$ carbonate) straddles the boundary in the open ocean and adjacent basins such as the Mediterranean, and has been identified in Oued Akrech [12] and in the Salé drill core [13]. In the continental realm, a significant shift in the opposite direction is found in terrestrial $\delta^{13} \mathrm{C}$. Despite being diachronous on a global scale, the shift approximates the $\mathrm{T}-\mathrm{M}$ boundary better than the Miocene-Pliocene boundary as suggested by Cerling et al. [44]. The acceleration in the world-wide expansion of $\mathrm{C} 4$ grasses, which is associated with the terrestrial $\delta^{13} \mathrm{C}$ shift around the T-M boundary, resulted in more open habitats on most continents. Although there is no evidence for mammal turnovers exactly at the boundary, major diversity drops and/or shifts from browsing to grazing habits occurred in mammal communities in Asia, Africa and North America between 8 and $6.5 \mathrm{Ma}[45,46]$.

\section{Towards a stable geological time scale}

In recent years, the application of the astronomical dating technique has resulted in astronomical time scales for the entire Pliocene-Pleistocene which now underlie the standard geological time scale for the same time interval [47]. One of the advantages of such time scales is their high resolution and the fact that they have to undergo no or only minor modification in the future once the underlying tuning is correct. An important additional advantage of the astronomical dating technique is that the PliocenePleistocene boundary as well as the more recently defined GSSPs of the Gelasian and Piacenzian are defined at lithological marker beds that are an integral part of the astronomically tuned cyclostratigraphic framework. As a consequence, these GSSPs are directly tied via first-order calibrations to the standard geological time scale. With the emergence of similar astronomical time scales for the Miocene [6], the same strategy has been followed for selecting the Messinian GSSP. Other requirements being equal, cyclostratigraphy played an important role in selecting Oued Akrech as the most suitable section - and level - for defining the Messinian GSSP. The astronomical tuning thus guarantees a direct first-order calibration of the Messinian GSSP to the standard geological time scale once, as anticipated, the late Miocene part of the astronomical time scale has been incorporated.

\section{Conclusions}

Sedimentary cycle patterns in combination with an integrated magnetostratigraphy and calcareous plankton biostratigraphy allow section Oued Akrech to be astronomically tuned and to be correlated cyclostratigraphically to time-equivalent sections in the Mediterranean.

The astronomical age of the Messinian GSSP formally defined at the base of the reddish layer No. 15 in section Oued Akrech arrives at 7.251 Ma if the La90 $(1,1)$ solution is used to compute the astronomical target curves. The GSSP coincides closely with the G. miotumida gr. FRO and the A. delicatus FO. Successive FOs of marker species of the Amaurolithus genus and the Late Miocene Carbon Shift allow worldwide recognition of the boundary in the marine realm, while the magnetostratigraphic calibration of the boundary in the middle of the reversed subchron $\mathrm{C} 3 \mathrm{Br}$.1r allows recognition of the boundary in the marine and continental realms.

The accurate and high-resolution age control provided by the astronomical tuning in combination with the calcareous plankton astrobiochronology will allow a better understanding of the onset of the Messinian salinity crisis. 


\section{Acknowledgements}

We gratefully thank Dr M. Dahmani of the 'Ministère de l'Energie et des Mines' for his very helpful collaboration and Sandra Gaboardi, Richard Benson and Kruna Rakic-El Bied for their help in the field. Dick, we will always remember you for lending us your universal plug adapter so that you were unable to shave for almost two weeks. This study was partly supported by the Netherlands Geosciences Foundation (GOA) with financial aid from the Netherlands Organisation of Scientific Research (NWO). [RV]

\section{References}

[1] K. Mayer-Eymar, Catalogue systématique et descriptif des fossiles des terrains tertiaires qui se trouvent du Musée fédéral de Zürich, Zürich, 1867.

[2] R. Selli, Il Messiniano Mayer-Eymar 1867. Proposta di un neostratotipo, Giorn. Geol. 28 (1960) 1-34.

[3] F.J. Sierro, The replacement of the 'Globorotalia menardii' group by the Goborotalia miotumida group: An aid to recognising the Tortonian-Messinian boundary in the Mediterranean and adjacent Atlantic, Mar. Micropaleontol. 9 (1985) 525-535.

[4] F.J. Sierro, J.A. Flores, J. Civis, J.A. González Delgado, New criteria for the correlation of the Andalusian and Messinian stages, Ann. Inst. Geol. Publ. Hung. 70 (1987) 355-361.

[5] F.J. Sierro, J.A. Flores, J. Civis, J.A. González Delgado, G. Francés, Late Miocene globorotaliid event-stratigraphy and biogeography in the NE-Atlantic and Mediterranean, Mar. Micropaleontol. 21 (1993) 143-168.

[6] F.J. Hilgen, W. Krijgsman, C.G. Langereis, L.J. Lourens, A. Santarelli, W.J. Zachariasse, Extending the astronomical (polarity) time scale into the Miocene, Earth Planet. Sci. Lett. 136 (1995) 495-510.

[7] W. Krijgsman, F.J. Hilgen, I. Raffi, F.J. Sierro, D.S. Wilson, Chronology, causes and progression of the Messinian salinity crisis, Nature 400 (1999) 652-655.

[8] F.J. Hilgen, W. Krijgsman, Cyclostratigraphy and astrochronology of the Tripoli diatomite formation (pre-evaporite Messinian, Sicily, Italy), Terra Nova 11 (1999) 1622.

[9] N.J. Shackleton, S. Crowhurst, Sediment fluxes based on an orbitally tuned time scale $5 \mathrm{Ma}$ to $14 \mathrm{Ma}$, Site 926, Proc. ODP, Sci. Results 154 (1997) 69-82.

[10] R.H. Benson, K. Rakic-El Bied, G. Bonaduce, An important current reversal (influx) in the Rifian Corridor (Morocco) at the Tortonian-Messinian boundary: The end of Tethys Ocean, Paleoceanography 6 (1991) 164-192.

[11] R.H. Benson, L.-A. Hayek, D.A. Hodell, K. Rakic El-
Bied, Extending the climatic precession curve back into the late Miocene by signature template comparison, $\mathrm{Pa}$ leoceanography 10 (1995) 5-20.

[12] D.A. Hodell, R.H. Benson, J.P. Kennett, A. Boersma, K. Rakic-El Bied, Stable isotope stratigraphy of latest Miocene sequences in northwest Morocco: The Bou Regreg section, Paleoceanography 4 (1989) 467-482.

[13] D.A. Hodell, R.H. Benson, D.V. Kent, A. Boersma, K. Rakic-El Bied, Magnetostratigraphic, biostratigraphic, and stable isotope stratigraphy of an Upper Miocene drill core from the Sale Briqueterie (northwestern Morocco): A high-resolution chronology for the Messinian stage, Paleoceanography 9 (1994) 835-855.

[14] F.J. Hilgen, W. Krijgsman, C.G. Langereis, W.J. Zachariasse, S. Iaccarino, G. Villa, R.H. Benson, M. Dahmani, The Global Boundary Stratotype Section and Point (GSSP) of the Messinian Stage (Uppermost Miocene): A proposal, Neogene Newslett. 5 (1998) 55-77.

[15] F.J. Hilgen, S. Iaccarino, W. Krijgsman, C.G. Langereis, G. Villa, W.J. Zachariasse, The Global Boundary Stratotype Section and Point (GSSP) of the Messinian Stage (uppermost Miocene), Epidodes (2000) submitted.

[16] R.H. Benson, K. Rakic-El Bied, The Bou Regreg section, Morocco: Proposed Global Boundary Stratotype Section and Point of the Pliocene, Notes Mém. Serv. géol. Maroc 383 (1996) 51-150.

[17] A. Bossio, K. Rakich El-Bied, L. Gianelli, R. Mazzei, A. Russo, G. Salvatorini, Corrélation de quelques sections stratigraphiques du Mio-Pliocene de la zone Atlantique du Maroc avec les stratotypes du Bassin Méditerranéen sur la base de foraminifères planctoniques, nannoplancton calcaire et Ostracodes, Atti Soc. Toscana Sci. Nat. Mem. 83 (1976) 121-137.

[18] R. Wernli, Les foraminifères planktoniques de la limite mio-pliocène dans les environs de Rabat (Maroc), Ecl. Geol. Helv. 70 (1977) 143-191.

[19] M.B. Cita, W.B.F. Ryan, The Bou Regreg section of the Atlantic Coast of Morocco. Evidence, timing and significance of a late Miocene regressive phase, Riv. Ital. Palèontol. 84 (1978) 1051-1082.

[20] R. Barbieri, Foraminiferal paleoecology at the TortonianMessinian boundary, Atlantic coast of northwestern Morocco, J. Foraminifer. Res. 28 (1998) 102-123.

[21] R.C. Tjalsma, Stratigraphy and foraminifera of the Neogene of the Eastern Guadalquivir basin, S. Spain, Utrecht Micropal. Bull. 4 (1971) 1-161.

[22] G.H. Scott, S. Bishop, B.J. Burt, Guide to some Neogene globorotalids (Foraminiferida) from New Zealand, New Zealand Geol. Survey Paleont. Bull. 61, 1990.

[23] G.H. Scott, Upper Miocene biostratigraphy: Does Globorotalia conomiozea occur in the Messinian?, Rev. Esp. Micropaleont. 12 (1980) 489-506.

[24] T. Fronval, E. Jansen, Late Neogene paleoclimate and paleoceanography in the Iceland-Norwegian Sea: Evidence from the Iceland and Voring Plateaus, in: J. Thiede et al. (eds.), Proc. ODP, Sci. Results 151 (1996) 455-468.

[25] W. Krijgsman, C.G. Langereis, W.J. Zachariasse, M. Boc- 
caletti, G. Moratti, R. Gelati, S. Iaccarino, G. Papani, G. Villa, Late Neogene evolution of the Taza-Guercif Basin (Rifian Corridor), Morocco and implications for the Messinian salinity crisis, Mar. Geol. 153 (1999) 147-160.

[26] H. Feinberg, H.G. Lorenz, Nouvelles données stratigraphiques sur le Miocene supérieur et le Pliocene du Maroc Nord Occidental, Notes Serv. Geol. Maroc 30 (1970) 2126.

[27] J. Zhang, D.B. Scott, Integrated stratigraphy and paleoceanography of the Messinian (latest Miocene) across the North Atlantic Ocean, Mar. Micropaleontol. 29 (1996) 1-36.

[28] M. Bernini, M. Boccaletti, J. El Mokhtari, R. Gelati, S. Iacarino, G. Moratti, G. Papani, Données stratigraphiques nouvelles sur le Miocène supérieur du bassin da Taza Guercif (Maroc nord-oriental), Bull. Soc. Géol. Fr. 163 (1992) 73-76.

[29] A. Negri, G. Villa, Calcareous nannofossil biostratigraphy, biochronology, paleoecology at the Tortonian/Messinian boundary of the Faneromeni section, Palaeogeogr. Palaeoclimatol. Palaeoecol. 156 (2000) 195-209.

[30] W. Krijgsman, F.J. Hilgen, C.G. Langereis, W.J. Zachariasse, The age of the Tortonian/Messinian boundary, Earth Planet. Sci. Lett. 121 (1994) 533-547.

[31] W. Krijgsman, F.J. Hilgen, C.G. Langereis, A. Santarelli, W.J. Zachariasse, Late Miocene magnetostratigraphy, biostratigraphy and cyclostratigraphy from the Mediterranean, Earth Planet. Sci. Lett. 136 (1995) 475-494.

[32] W. Krijgsman, F.J. Hilgen, A. Negri, J. Wijbrans, W.J. Zachariasse, The Monte del Casino section (northern Apennines, Italy): A potential Tortonian/Messinian boundary stratotype?, Palaeogeogr. Palaeoclimatol. Palaeoecol. 133 (1997) 27-47.

[33] A. Negri, S. Giunta, F. Hilgen, W. Krijgsman, G.B. Vai, Calcareous nannofossil biostratigraphy of the Monte del Casino section (northern Apennines, Italy) and paleoceanographic consideration on the origin of the late Miocene sapropels, Mar. Micropaleontol. 36 (1999) 13-30.

[34] L.J. Lourens, A. Antonarakou, F.J. Hilgen, A.A.M. Van Hoof, C. Vergnaud-Grazzini, W.J. Zachariasse, Evaluation of the Plio-Pleistocene astronomical timescale, $\mathrm{Pa}$ leoceanography 11 (1996) 391-413.

[35] L.J. Lourens, F.J. Hilgen, Long periodic variations in the Earth's obliquity and their relation to third-order eustatic cycles and late Neogene glaciations, Quat. Int. 40 (1997) $43-52$.

[36] J. Remane, M.G. Bassett, J.W. Cowie, K.H. Gohrbrandt,
H. Richard Lane, O. Michelsen, W. Naiwen, Revised guidelines for the establisment of global chronostratigraphic standards by the International Commission on Stratigraphy (ICS), Episodes 19 (1996) 77-81.

[37] R.H. Benson, D.A. Hodell, Comment on 'A critical evaluation of the Miocene/Pliocene boundary as defined in the Mediterranean', Earth Planet. Sci. Lett. 124 (1994) 245 250.

[38] I. Raffi, D. Rio, A. d'Atri, E. Fornaciari, S. Rocchetti, Quantitative distribution patterns and biomagnetostratigraphy of Middle to Late Miocene calcareous nannofossils from equatorial Indian and Pacific Oceans (Legs 115, 130, and 138), Proc. ODP, Sci. Results 138 (1995) 479-502.

[39] J. Backman, I. Raffi, Calibration of Miocene nannofossil events to orbitally-tuned cyclostratigraphies from Ceara Rise, Proc. ODP., Sci. Results 154 (1997) 83-99.

[40] E. Martini, Standard Tertiary and Quaternary calcareous nannoplankton zonation, Proc. II Planktonic Conf., Rome 1970, Vol. 2, 1971, pp. 739-785.

[41] H. Okada, D. Bukry, Supplementary modification and introduction of code numbers to the low-latitude coccolith biostratigraphic zonation (Bukry, 1973; 1975), Mar. Micropaleontol. 51 (1980) 321-325.

[42] W.A. Berggren, D.V. Kent, C.C. Swisher, M.-P. Aubry, A revised Cenozoic geochronology and chronostratigraphy. in: Geochronology, Time Scales and Global Stratigraphic Correlation, SEPM Spec. Publ. 54 (1995) 129-212.

[43] S. Iaccarino, Mediterranean Miocene and Pliocene planktonic foraminifera, in: H.M. Bolli, J.B. Saunders, K. Perch-Nielsen (Eds.), Plankton Stratigraphy, Cambridge University Press, Cambridge, 1985, pp. 283-314.

[44] T.E. Cerling, J.M. Harris, B.J. MacFadden, M.G. Leakey, J. Quade, V. Eisenmann, J.R. Ehleringer, Global vegetation changes through the Miocene/Pliocene boundary, Nature 389 (1997) 153-158.

[45] J. Alroy, Conjunction among taxonomic distributions and the Miocene mammalian biochronology of the Great Plains, Paleobiology 18 (1992) 326-343.

[46] M.E. Morgan, J.D. Kingston, B.D. Marino, Carbon isotopic evidence for the emergence of $\mathrm{C} 4$ plants in the Neogene from Pakistan and Kenya, Nature 367 (1994) 162165.

[47] W.A. Berggren, F.J. Hilgen, C.G. Langereis, D.V. Kent, J.D. Obradovitch, I. Raffi, M. Raymo, N.J. Shackleton, Late Neogene (Pliocene-Pleistocene) chronology: New perspectives in high-resolution stratigraphy, Geol. Soc. Am. Bull. 107 (1995) 1272-1287. 